TARBIYATUNA: Kajian Pendidikan Islam

Volume 3 Nomor 1 Tahun 2019

Print ISSN : 2597-4807

Online ISSN : 2622-1942

\title{
Faktor-Faktor Penyebab Kenakalan Remaja di Lebak Mulyo Kecamatan Kemuning Kota Palembang
}

\author{
Andrianto, \\ Fakultas Ilmu Tarbiyah dan Keguruan, UIN Sunan Kalijaga Yogyakarta \\ e-mail: andriantoanto949@gmail.com
}

\begin{abstract}
This research included in the research field (Field Resarch) is descriptive qualitative. As for informants here are 5 parents who have a child from a year 13-18 categorized 5 naughty teen teenager, 5 religious figures, public figures, 51 the head Lurah and 1 Chair RT. Whereas the collection of data in this study using the method observation, in-depth interviews and documentation. The analysis in this study uses data reduction techniques, presentation of data and verification.The study found that factors what causes juvenile delinquency in Lebak Mulyo Subdistrict Kemuning Palembang of which is the lack of attention to the elderly, the social environment is not good friends, hanging out and economic factors and efforts are being made to overcome parents ' juvenile delinquency in Lebak Mulyo Subdistrict Kemuning Palembang was by way of educating his son well, send in the religious school, giving Religious lessons, put his son in boarding school. Efforts are being made to overcome Neighborhood Party juvenile delinquency in Lebak Mulyo Subdistrict Kemuning Palembang was a teenager was given a briefing on religion, enlightenment, an appeal from Mr. RT so that people do not commit crimes khususya teens, created karangtaruna, futsal, sports programs are given the training, given the students if a less capable, given the youth, given the direction of religion, given the job that generates its own income and old people continued to flee into a more well, there should be a study of religious education, further enhance karang taruna, recitation and Assembly.
\end{abstract}

Keywords: juvenile delinquency, Lebak Mulyo, Palembang City

\begin{tabular}{|c|c|c|}
\hline Accepted: & Reviewed: & Publised: \\
Desember 25 2018 & Januari 17 2019 & Februari 28 2019 \\
\hline
\end{tabular}

\section{PENDAHULUAN}

Remaja adalah rentangan kehidupan manusia, yang berlangsung sejak berakhirnya masa kanak-kanak sampai awal dewasa. Oleh karena itu sering juga disebut masa peralihan antara masa kanak-kanak dengan masa dewasa (Hawi,

This work is licensed under Creative Commons Attribution Non Commercial 4.0 International License Available iaiibrahimy.ac.id 
2008:81). Batasan dan pengertian usia remaja yaitu sekitar 13-21 tahun. Sebagaimana halnya tahapan perkembangan pada setiap fase, remaja pun memiliki karakteristik yang membedakannya dengan masa-masa yang lain (Wahab, 2015:103).

Sedangkan pengertian masa remaja banyak yang memberikan penjelasan dengan pengertian sama dengan masa pubertas, masa adolesence, masa kegoncangan, masa oleng, masa belum menemukan nilai kebenaran. Yang berarti pada masa remaja tersebut sesuai dengan perkembangan psikisnya yang juga ditentukan oleh perkembangan fisiknya maka pada remaja tersebut perlu diberikan atau pengarahan yang betul-betul harus bijak dan tepat agar para remaja tersebut tidak berkembang kearah yang tidak diharapkan (Wahab, 2015:103).

Jadi remaja adalah berakhirnya masa anak-anak sampai awal dewasa, usia remaja 13-22 tahun sebagai mana tahap perkembangan. Masa remaja adalah masa pancaroba penuh dengan kegelisahan serta kebimbangan untuk menemukan jati diri sesungguhnya yang ada didalam dirinya.

Salah satu sumber dari pendidikan karakter adalah budaya, karena kehidupan masyarakat selalu didasari oleh nilai-nilai budaya yang diakui di masyarakat tersebut, nilai budaya dijadikan dasar dalam memberi makna terhadap suatu konsep dan arti dari perilaku komunikasi masyarakat tersebut. Maka dari itu pelaksanaan pendidikan karakter di sekolah dasar tidak lepas dari pengenalan nilai-nilai budaya lokal yang telah menjadi pandangan hidup secara turun temurun dalam suatu tradisi masyarakat (Saidah, 2018: 3039).

Kenakalan remaja atau delinquency anak-anak yang merupakan istilah lain dari juvenile delinquency, adalah salah satu problem lama yang senantiasa muncul di tengah-tengah masyarakat. Masalah tersebut hidup, berkembang dan membawa akibat tersendiri sepanjang masa, seusia kelompok masyarakat manusia terbentuk. Delinkwensi anak-anak sebagai salah satu problem sosial sangat mengganggu keharmonisan, juga keutuhan segala nilai dan keutuhan segala nilai dan kebutuhan dasar kehidupan sosial. Dalam kenyataan delinquency anak-anak atau kenakalan remaja merupakan nilai-nilai moral, nilai-nilai susila, nilai-nilai luhur agama dan beberapa aspek pokok yang terkandung di dalamnya, serta norma-norma hukum yang hidup dan tumbuh didalamnya baik hukum tertulis maupun hukum yang tidak tertulis.

Di samping nilai-nilai dasar kehidupan sosial, juga dasar kehidupan sosial tidak luput dari gangguan delinkwensi anak-anak (Sudarsono, 2005). Menurut Zakiah Daradzat kenakalan anak-anak adalah ungkapan dari seorang anak dari orang yang kaya dan berpangkat, mencuri atau melakukan kejahatan-kejahatan 
tertentu, maka kejahatan atau kenakalan yang dilakukan oleh anak itu bukanlah karena ia kekurangan uang dari orang tuanya, akan tetapi adalah ungkapan dari rasa tidak puas, kecewa atau rasa tertekan, merasa kurang mendapat perhatian, kurang merasa kasih sayang orang tua dan sebagainya (Sudarsono, 2012:48).

Suatu perbuatan itu disebut delinquency apabila perbuatan-perbuatan tersebut bertentangan dengan norma-norma yang ada pada masyarakat di mana ia hidup, suatu perbuatan yang anti sosial dimana didalamnya terkandung unsurunsur anti normatif. Juvenile delinquency (kenakalan remaja) bukan hanya merupakan perbuatan anak yang melawan hukum semata akan tetapi juga termasuk didalamnya perbuatan yang melanggar norma masyarakat. Dewasa ini sering terjadi seorang anak digolongkan sebagai delinquency jika pada anak tersebut nampak adanya kecendrungan-kecendrungan anti sosial yang sangat memuncak sehingga perbuatan-perbuatan tersebut menimbulkan gangguangangguan terhadap keamana, ketentraman dan keterlibatan masyarakat, misalnya pencurian, pembunuhan, penganianyaan, penipuan, penggelapan dan glandangan serta perbuatan-perbuatan lain yang dilakukan oleh anak remaja yang meresahkan masyarakat (Sudarsono, 2012:48).

Jadi kenakalan remaja suatu sikap yang tidak terpuji, perbuatan yang super interaktif yang akan berdampak kearah yang negatif, kearah yang bisa menghancurkan masa depan, seperti mencuri, minum-minuman keras, merokok dan tawuran yang akan merugikan masa depan. Kenakalan remaja juga akan menghancurkan masa depan, menghancurkan cita-cita yang di impi-impikan dan menghancurkan harapan bangsa.

Kenakalan remaja yang sering terjadi didalam masyarakat bukanlah suatu keadaan yang berdiri sendiri. Kenakalan remaja tersebut timbul karena adanya beberapa sebab dan tiap-tiap sebab dapat ditanggulangi dengan cara-cara tertentu.

Kondisi sosial yang patologis telah menyebabkan kontrol orang dewasa terhadap para remaja dan adolesens jadi semakin berkurang. Maka sumber utamanya pada hakikatnya bukanlah masalah yang patologisnya, akan tetapi faktor kecepatan perubahan sosial (bahkan ada percepatan perubahannya), sehingga terjadi banyak kelabilan pada sektor politik, ekonomi, pendidikan, lingkungan keluarga dan lembaga-lembaga sosial ditengah masyarakat. Karena itu norma, kontrol dan sanksi sosial menjadi semakin melemah, yang membawa akibat anak-anak dan para remaja menjadi brutal tidak terkontrol dan tidak terkendali (Kartono, 2003:7374).

Kekaburan yang dialami para remaja dan dorongan masyarakat yang tidak berfungsi positif menyebabkan timbulnya krisis identitas bagi remaja. Remaja 
menemukan dirinya mengenai apa yang harus dilakukan kapan dan bagaimana harus dilakukan, berarti remaja tersebut telah mampu menunjukkan identitas yang sebenarnya dan dia akan mudah melakukan perannya dimasyarakat, tetapi bila ia gagal menemukan identitas dirinya maka ia memiliki identitas negatif dan akan merasakan kesulitan didalam melakukan peran ditengah masyarakat (Wahab, 2015:108).

Untuk itu, peran orang tua masih mutlak diperlukan oleh remaja. Orang tua harus tetap memberikan bimbingan keagamaan dengan remaja. Kondisi keluarga yang tidak harmonis, ataupun orang tua yang tidak memberikan kasih sayang yang utuh dan berteman dengan kelompok sebaya yang kurang menghargai nilai-nilai Agama, maka remaja pun akan bersikap kurang baik atau asusila. Misalnya free sex, minuman keras, membuat onar, menghisap ganja dan sebagainya (Zuhdiyah, 2012:76).

Fenomena lain yang kerap muncul adalah suatu kondisi lain yang sebenarnya akibat dari kasus tertentu, dalam hal ini dapat diambil contoh adanya hak anak-anak sekolah yang berasal dari keluarga yang kurang mengutamakan dan mementingkan anak dalam belajar. Biasanya anak-anak tersebut bersikap acuh terhadap tugas-tugas sekolah dan kehilangan rasa tanggung jawab di dalamnya, sikap tersebut biasanya.

Di tengah-tengah kehidupan masyarakat sering muncul keresahan karena kejahatan, seperti: tindakan-tindakan kekerasan, pemerkosaan, pencurian dan penipuan. Kejahatan-kejahatan tersebut dilakukan oleh penjahat dari tingkatan umur yang sangat heterogen, sebab terdiri dari kelompok umur lanjut usia, kelompok dewasa dan tidak ketinggalan anak remaja. Bagi kelompok umur remaja sebagian pendorong keinginan untuk berbuat jahat tersebut muncul karena bacaan, pengaruh film dan gambar-gambar porno lainnya (Zuhdiyah, 2012:29).

Hal yang perlu dilakukan ialah eksistensi orang tua dalam menekankan sejak dini, pengaruh lingkungan sekitar terhadap pola sikap dan tingkah laku yang tertanam pada diri anak. Sebab lingkungan memberi pengaruh sangat kuat terhadap perilaku anak-anak.

Namun pada kenyataan peneliti melihat pada kehidupan masyarakat di Lebak Mulyo Kecamatan Kemuning Kota Palembang. Dari observasi pada hari kamis tanggal 20-10-2016 yang saya lakukan dimana ternyata masih ada remaja yang melakukan penyimpangan dari yang seharusnya ia lakukan di usianya. Perilaku yang sering mereka lakukan ialah sering bolos sekolah, mencuri, merokok, minum-minuman keras pada usia dini, nongkrong-nongkrong di jembatan dan berkata yang tidak baik. Dari keterangan yang ini jelas bahwa 
tingkah laku anak-anak di Lebak Mulyo Kecamatan Kemuning Kota Palembang, tersebut merupakan masalah yang perlu diteliti dan dicari pemecahan masalahnya.

\section{METODE PENELITIAN}

Penelitian ini termasuk dalam penelitian lapangan (Field Resarch) yang bersifat kualitatif deskriptif. Adapun informan disini adalah 5 orang tua yang mempuyai anak berumur 13-18 tahun yang di kategorikan remaja nakal, 5 remaja, 5 tokoh Agama, 5 tokoh masyarakat, 1 Kepala Lurah dan 1 Ketua RT. Sedangkan pengumpulan data dalam penelitian ini menggunakan metode observasi, wawancara mendalam dan dokumentasi. Analisis dalam penelitian ini menggunakan teknik reduksi data, penyajian data dan verifikasi.

\section{HASIL ANALISIS DAN PEMBAHASAN}

\section{A. Pengertian Remaja}

Remaja dalam bahasa aslinya disebut adolescence, berasal dari bahasa latin adolescere yang artinya "tumbuh untuk mencapai kematangan". Bangsa primitif dan orang-orang purbakala memandang masa puber dan masa remaja tidak berbeda dengan periode lain dalam rentang kehidupan (Ali \& Asrori, 2012:10).

Menurut Mappire, masa remaja ialah berlangsungnya antara umur 12 tahun sampai dengan 21 tahun bagi wanita, 13 tahun sampai dengan 22 tahun bagi pria. Menurut hukum di Amerika Serikat saat ini individu di anggap telah dewasa apabila telah mencapai usia 18 tahun dan bukan 21 tahun, pada usia ini umumnya anak sedang duduk di bangku sekolah menengah (Ali \& Asrori, 2012:9).

Pada masa ini remaja juga sedang mengalami perkembangan pesat dalam aspek intelektual, transpormasi intelektual dari cara berpikir didalam berinteraksi dalam masyarakat. Remaja sebetulnya tidak mempunyai tempat yang jelas, mereka sudah tidak termasuk kedalam golongan anak-anak, tetapi belum juga diterima sepenuhnya untuk diterima kegolongan orang dewasa. Remaja berada diantara anak dan dewasa. Oleh karena itu, remaja sering disebut dengan fase "mencari jati diri" atau fase "topan dan badai" (Ali \& Asrori, 2012:10).

Dengan demikian pada masa remaja merupakan masa perkembangan yang mana ia harus bisa menyesuaikan diri pada kehidupan masyarakat. Sebab pada masa ini sangat diperlukan pengawasan yang lebih dari orang tua agar anak mereka tidak termasuk kedalam pergaulan yang negatif dan itu bisa merugikan dirinya sendiri maupun masyarakat sekitarnya.

Zakiyah Daradjat memberikan 4 (empat) sudut pandang tentang pengertian remaja yaitu: 
1. Remaja dalam pengertian psikologis dan pendidikan, yaitu tahapan peralihan yang datang setelah masa kanak-kanak berakhir yang ditandai oleh pertumbuhan fisik yang cepat.

2. Remaja dalam pengertian masyarakat, dalam hal ini remaja sangat bergantung pada kondisi sosial dan penerimaan masyarakat setempat. Pada masyarakat pedesaan yang sangat sederhana mungkin masa remja tidak mereka kekal, sebab begitu mereka tumbuh besar dan kuat, mereka dianggap telah mampu melakukan pekerjaan seperti yang dilakukan orang tuanya. Maka saat itulah mereka diterima dalam lingkungan masyarakat, pendapatnya didengar dan diperhatikan, mereka juga sudah berlatih untuk memikul tanggung jawab keluarga.

3. Remaja dalam pandangan hukum dan perundang-undangan, remaja dalam pengertian isi dibatasi pada usia 11-18 tahun. Karena pada usia tersebut dalam pandangan hukum positif telah dianggap dewasa jika berbuat yang melanggar hukum akan diberikan sanksi layaknya orang dewasa atau bukan anak-anak lagi.

4. Remaja dari segi ajaran Islam, ialah remaja dalam islam sering disebut dengan kata (baligh) yang mana seorang anak yang sudah dikenal hukum dalam mengerjakan hukum Islam dalam kehidupan sehari-hari atau kata lain terhadap mereka yang telah baligh dan berakal berlakulah ketentuan hukum Islam (Daradjat, 2006:56).

Remaja dari segi ajaran Islam, secara eksplinsit kata yang berarti remaja tidak ada dalam Islam, namun dalam Al-Qur'an yang menyebut sinonim kata remaja yakni pemuda atau anak yang sudah baligh yang menunjukkan seseorang tidak kanak-kanak lagi misalnya terdapat dalam Al-Qur'an surat An-Nur ayat 58,

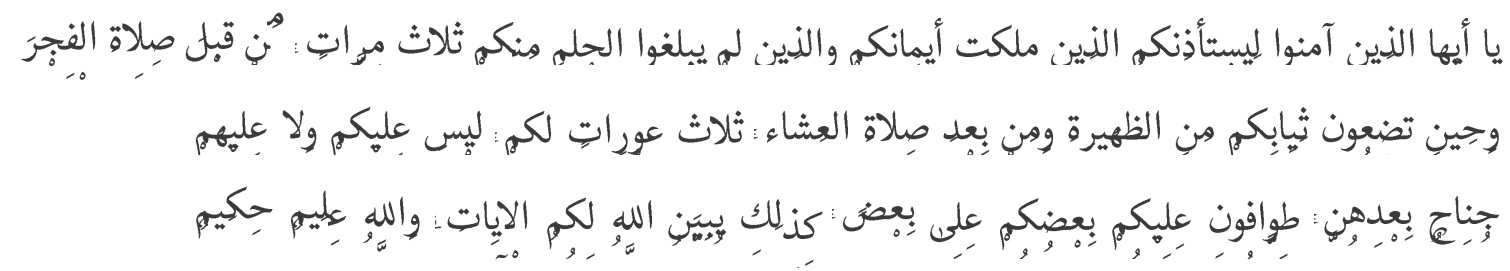

Artinya: "Hai orang-orang yang beriman, hendaklah budak-budak (lelaki dan wanita) yang kamu miliki, dan orang-orang yang belum balig di antara kamu, meminta izin kepada kamu tiga kali (dalam satu hari) yaitu: sebelum sembahyang subuh, ketika kamu menanggalkan Pakaian (luar)mu di tengah hari dan sesudah sembahyang Isya'. (Itulah) tiga 'aurat bagi kamu. tidak ada dosa atasmu dan tidak (pula) atas mereka selain dari (tiga waktu) itu. mereka melayani kamu, sebahagian kamu (ada keperluan) kepada sebahagian (yang lain). Demikianlah Allah 
menjelaskan ayat-ayat bagi kamu. dan Allah Maha mengetahui lagi Maha Bijaksana".

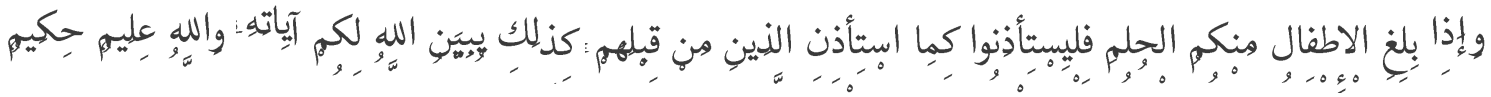

Artinya: "Dan apabila anak-anakmu Telah sampai umur balig, Maka hendaklah mereka meminta izin, seperti orang-orang yang sebelum mereka meminta izin. Demikianlah Allah menjelaskan ayat-ayat-Nya. dan Allah Maha mengetahui lagi Maha Bijaksana" (Departemen Agama RI, 2005:357-358).

Pada kedua ayat tersebut terdapat istilah kata baligh yang dikaitkan dengan mimpi. Kata baligh dalam istilah hukum Islam digunakan untuk penentuan umur awal kewajiban melaksanakan hukum Islam dalam kehidupan sehari-hari.

Dapat diambil kesimpulan dalam pandangan Islam istilah remaja tidak dikenal dalam Islam. Namun hanya dikenal dua keadaan atau masa dalam berhadapan dengan hukum syari'at Islam, Yakni, 1) masa kanak-kanak yakni ketika manusia belum sempurna akal, fisik dan jiwanya sehingga mereka belum dibebani kewajiban-kewajiban agama, akan tetapi merupakan masa persiapan agar mudah untuk mendidiknya ke masa yang akan datang dengan baik. 2) masa akil baligh atau mukallaf yakni ketika seseorang manusia mulai dibebani kewajiban-kewajiban agama yang ditandai dengan mengalami mimpi basah pada anak laki-laki dan haid atau datang bulan bagi anak perempuan dan telah diberi kewajiban untuk mentaati hukum syari'at Islam.

\section{B. Kenakalan pada Remaja}

Kenakalan pada anak sering terjadi pada kehidupan didalam keluarga, orang tua sangat berperan penting dalam mengatasi kenakalan pada anak. Keluarga adalah tempat perkembangan awal seorang anak, sejak kelahiran sampai proses perkembangan jasmani dan rohani berikutnya. Bagi seorang anak, keluarga memiliki arti dan fungsi yang vital bagi kelangsungan hidup maupun dalam menemukan makna dan tujuan hidupnya. Untuk mencapai perkembangannya seorang anak membutuhkan kasih sayang, perhatian dan rasa aman untuk berlindung dari orang tuanya.

Kenakalan pada anak menurut pendapat Sutherland tahun 1960 menyatakan bahwa, sebab-sebab kejahatan anak remaja itu tidak hanya terletak 
pada lingkungan familial dan tetangga saja, akan tetapi, terutama sekali, disebabkan oleh konteks kulturalnya (Kartono, 2003:30).

Kenakalan remaja meliputi perbuatan-perbuatan yang sering menimbulkan keresahan dilingkungan masyarakat, sekolah maupun keluarga. Contoh yang sangat sederhana dalam hal ini antara lain, pencurian oleh anak-anak dan remaja, perkelahian dikalangan anak didik yang kerap sekali terjadi antar sekolah. Kemudian sikap anak yang memusuhi orang tua dan sanak saudaranya atau perbuatan lain yang tercela seperti mengisap ganja, minuman keras dan mencoretcoret yang tidak pada tempatnya.

\section{Faktor-faktor Kenakalan Remaja}

1. Bersifat Umum

a. Bersifat Umum

1) Faktor-faktor langsung

a) Kegagalan pendidikan atau pendidikan agama yang dilakukan keluarga, guru, guru agama dan masyarakat terutama oleh keluarga sebagai penyebab utama.

b) Kondisi sosial yang kurang menguntungkan bagi pertumbuhan dan perkembangan remaja secara wajar.

2) Faktor-faktor tidak langsung

a) Faktor sosial politik, sosial ekonomi, sosial budaya, masalah urbanisasi, penyakit masyarakat, teknologi canggih, komunikasi cepat yang bersifat negatif mempercepat timbulnya kenakalan pada remaja.

b. Bersifat Khusus

1) Faktor Intern

a) Cacat lahir/keturunan yang bersifat biologis atau psykis.

b) Pembawaan bakat yang negatif dan sukar untuk diarahkan, sukar dikendalikan secara wajar.

c) Pemenuhan kebutuhan pokok yang tak seimbang dengan keinginan anak-anak.

d) Kurang penyesuaian diri dalam lingkungan.

e) Pengendalian diri kurang terhadap hal-hal yang negatif atau dengan perkataan lain daya tahan lemah.

f) Tidak mempunyai kegemaran/hobi yang sehat, sehingga anak atau remaja mudah dipengaruhi oleh hal-hal yang negatif.

2) Faktor Ekstern

a) Dari lingkungan orang tua atau keluarga

(1) Rasa cinta kasih sayang yang tidak merata terhadap anak-anak.

(2) Kelahiran yang tidak dikehendaki oleh orang tuanya.

(3) Disharmoni atau broken home dalam rumah tangga orang tua.

(4) Kesibukan orang tua sehingga anaknya tak terhina.

(5) Kurang mengetahuicara-cara mendidik anak-anak yang baik. 
(6) Kurang contoh teladan yang baik dari orang tua.

(7) Kurang memberikan dasar pendidikan agama, mental, budi pekerti serta disiplin dan tanggung jawab yang baik oleh orang tua.

b) Dari lingkungan sekolah

(1) Kurang guru atau guru agama yang memenuhi syarat

(2) Biyaya pendidikan yang cukup tinggi

(3) Kesibukan guru untuk mencari tambahan penghasilan

(4) Penghasilan yang tidak tetap, misalnya didaktik metodik, kurikulum yang kurang menarik

(5) Kurang adanya kerjasama/hubungan guru dan orang tua murid

(6) Penilaian masyarakat/orang tua yang kurang terhadap tugas-tugas guru, akibatnya mengurangi wibawa guru

(7) Kurangnya pendidikan agama, budi pekerti serta kurangnya fasilitas pendidikan berupa sarana dan prasaran

(8) Faktor-faktor POLEKSOSBUD yang masih kurang menguntungkan bagi perkembangan remaja.

(a) Pengawasan orang tua/guru/masyarakat masih kurang

(b) Kurang diikut sertakan remaja dalam kegiatan kemasyarakatan

(c) Cara pendekatan pada remaja kurang tepat

(d) Kurangnya contoh/ teladan yang positif dari masyarakat

(e) Kehendaknya tidak dipenuhi dan kurang disalurkan secara wajar, kurang diberikan rasa tanggung jawab (Nasir, 2002:8688).

Faktor-faktor penyebab kenakalan pada anak adalah suatu perilaku yang dilakukan oleh anak dari sejak dini sampai dewasa, kenakalan ini sangat merugikan banyak orang terutama dirinya sendiri, dan masyarakat sekitar. Kenakalan pada anak remaja ini bukan hanya merupakan perbuatan anak yang melawan hukum semata akan tetapi juga termasuk didalamnya perbuatan yang melanggar norma masyarakat.

Simanjuntak dalam Aat Syafaat menyebutkan sebab-sebab terjadi kenakalan pada anak.

1. Faktor Internal.

a. Lemahnya pemahaman nilai-nilai Agama

b. Cacat keturunan yang bersifat biologis-psikis

c. Pembawaan yang negatif yang mengarah keperbuatan nakal

d. Ketidak seimbangan penemuan kebutuhan pokok dengan keinginan. Hal ini menimbulkan frustasi dan ketegangan

e. Ketidak mampuan menyesuaikan diri terhadap perubahan lingkungan sekitarnya

2. Faktor Eksternal 
a. Kurangnya perhatian, rasa cinta dari orang tua dan lingkungan

b. Kondisi keluarga tidak nyaman, lingkungan sekolah tidak kondusif dan kondisi masyarakat yang buruk

c. Terpengaruhnya terhadap lingkungan masyarakat sekitar

d. Kurangnya pemanfaatan waktu yang luang (Syafaat, 2008:75).

\section{Bentuk-bentuk Kenakalan Remaja}

Secara umum Muhammad Al-Zuhali dalam Aat Syafaat membagi wujud penyimpangan remaja menjadi enam bagian bentuk-bentuk kenakalan pada remaja yaitu sebagai berikut:

1. Penyimpangan Moral

Penyimpangan moral terjadi disebabkan oleh seseorang yang meninggalkan perilaku baik dan mulia, lalu menggantinya dengan perbuatan yang buruk. Seperti bersikap tidak mau tahu dengan lingkungan sekitarnya, mengikuti gaya dan model barat, tawuran dn nongkrong dipinggir jalan.

2. Penyimpangan Berfikir

Penyimpangan dalam berfikir dapat timbul disebabkan oleh adanya kekosongan pikiran, kekeringan rohani dan kedangkalan keyakinan.Orang yang menyimpang dalam berfikir akan senantiasa bingung terhadap serangan pemikiran yang dilakukan pihak asing, dia juga fanatik buta terhadap suku, bangsa, kelompok, profesi dan kasta. Dia selalu terbuai dengan khayalan dan hal-hal yang bersifat menyimpang atau jahat.

3. Penyimpangan Agama

Penyimpangan dalam bidang agama terlihat dari sikap ekstern seseorang dalam memahami ajaran agama. Sehingga ia fanatik terhadap mazhab atau kelompoknya, memilih untuk tidak bertuhan, skeptis terhadap kenyakinannya sendiri dan agama yang dianutnya, memperjual belikan ajaran agama, arogan terhadap prinsip-prinsip yang dipegang atau ajaran-ajaran tokoh masyarakat.

4. Penyimpangan Sosial dan Hukum

Penyimpangan dalam bidang ini telah kita lihat pada zaman sekarang ini seperti kekerasan, pengancaman, perampokan, pembunuhan, pembajakan, minuman keras, mengonsumsi narkoba dan penyimpangan seksual.

\section{Penyimpangan Mental}

Penyimpangan dalam maslah mental atau kejiwaan dpat dilihat dari sikap yang selalu merasa tersisih, kehilangan kepercanyaan diri, memiliki kepribadian ganda, kehilangan harapan masa depan, merasa selalu sial dan cepat berputus asa, gelis, dan sering bingung dan masih banyak lagi prilaku yang lainnya. 


\section{Penyimpangan Ekonomi}

Penyimpangan dalam hal ekonomi dapat berbentuk sikap congkak dan gengsi terhadap kekayaan yang dimiliki, boros, berpoya-poya, bermegah-megahan, glamor dalam berpakaian, busana dan perhiasan, membuang-buang waktu, bersikap materialistis dan suka menghambur-hamburkan harta (Syafaat, 2008:8384).

Kartini Kartono, yang menulis ada beberapa bentuk atau wujud dari perilaku delinquency ini ialah:

1. Kebut-kebutan di jalan yang mengganggu keamanan lalu lintas, dan membahayakan jiwa sendiri serta orang lain.

2. Perilaku ugal-ugalan, brandalan, urakan yang mengacaukan ketentraman milieu sekitarnya.

3. Perkelahian antar gang, antar kelompok, antar sekolah, antar suku (tawuran), sehingga kadang-kadang membawa korban jiwa.

4. Membolos sekolah lalu bergelandangan sepanjang jalan atau bersembunyi di tempat-tempat kecil sambil sambil melakukan eksperimen bermacammacam kedurjanaan dan tindak asusila.

5. Berpesta pora, sambil mabuk-mabukan.

6. Kecanduan dan ketagihan bahan narkotika yang erat bergandengan dengan tindakan kejahatan.

7. Perjudian dan bentuk-bentuk permainan lain dengan taruhan, sehingga mengakibatkan ekses kriminalitas.

8. Komersislisasi seks, penguguran janin oleh gadis-gadis delinquency dan pembunuhan bayi oleh ibu-ibu yang tidak kawin.

9. Tindakan radikal dan ekstrim dengan cara kekerasan, penculik dan pembunuhan yang dilakukan oleh anak-anak remaja (Kartono, 2003:22).

Sedangkan Dadang Hawari dalam Aat Syafaat mengatakan bahwa perilaku menyimpang oleh remaja sering kali merupakan gambaran dari kepribadian antisosial atau gangguan tingkah laku remaja yang ditandai dengan tiga atau lebih kriteria dari gejala-gejala berikut:

1. Sering membolos

2. Terlibat kenakalan (ditangkap atau diadili di pengadilan anak karena tingkah lakunya)

3. Dikelurkan atau diskors dari sekolah karena berlaku buruk

4. Seringkali lari dari rumah (minggat) dan bermalam diluar rumahnya

5. Selalu berbohong

6. Berulang-ulang melakukan hubungan seks, walaupun hubungannya belum akrab

7. Sering kali mabuk atau menyalah gunakan narkotika zat adiktif lainnya

8. Sering kali mencuri

9. Sering kali merusak barang milik orang lain 
10. Prestasi sekolah yang jauh dibawah taraf kemampuan kecerdasan (IO) sehingga berakibat tidak naik kelas

11. Sering kali melawan otoritas yang lebih tinggi seperti melawan guru dan orang tua, melawan aturan-aturan dirumah atau disekolah, tidak disiplin

12. Seringkali mulai perkelahian (Syafaat, 2008:82-83).

Dari uraian di atas dapat diketahui pad hakikatnya bentuk atau wujud kenakalan merupakan perilaku pelanggaran norma-norma yang berlaku di masyarakat, menimbulkan keresahan dan berdampak negatif bagi remaja dan lingkungan sekitarnya. Bentuk perilaku menyimpang ini pada masa yang akan datang harus dapat diminimalisir secara maksimal secara identifikasi penyebab yang telah disebut di awal, lalu mencari solusi yang komprehensif dan efektif.

\section{SIMPULAN}

Faktor-faktor penyebab kenakalan pada anak adalah suatu perilaku yang dilakukan oleh anak dari sejak dini sampai dewasa, kenakalan ini sangat merugikan banyak orang terutama dirinya sendiri, dan masyarakat sekitar. Kenakalan pada anak remaja ini bukan hanya merupakan perbuatan anak yang melawan hukum semata akan tetapi juga termasuk didalamnya perbuatan yang melanggar norma masyarakat. Faktor-faktor penyebab kenakalan remaja adalah faktor kurangnya perhatian orang tua, faktor lingkungan yang kurang mendukung, faktor ekonomi, faktor film negatif yang ditonton, faktor pergaulan bebas, faktor kurangnya pendidikan Agama, pendidikan yang tidak selesai, pengangguran, pengaruh game plestesien, narkoba, pencurian, minuman keras, berjudi, merokok, tawuran, situs-situs internet yang negatif, sekolahnya tidak lulus dan cita-cita terbengkalai.

Orang tua mengatasinya dengan cara mendidik anaknya dengan baik, menyekolahkan di sekolah Agama, memberikan pelajaran-pelajaran Agama, memasukkan anaknya di pesantren dan mengenalkan perbuatan yang baik dan perbuatan yang buruk. Upayanya remaja diberi pencerahan, pengarahan Agama, himbauan dari pak RT agar masyarakat tidak melakukan kejahatan khususya remaja, dibentuk karangtaruna, program olahraga putsal, diberi pelatihanpelatihan, diberi biyaya siswa kalo yang kurang mampu, diberi pembinaan remajaya, diberi pengarahan agama, diberi pekerjaan yang menghasilkan penghasilan sendiri dan orang tua terus hijrah menjadi yang lebih baik, harus ada kajian pendidikan agama, tingkatkan karang taruna, pengajian dan majelis taklim. 


\section{DAFTAR RUJUKAN :}

Ali, Mohammad \& Asrori, Mohammad. (2015). Psikologi Remaja. Jakarta: Bumi Aksara

Departemen Agama R.I. (2013). Al-Qur'an dan Terjemahannya. Bandung: Diponegoro

Kartono, Kartini. (2003). Patologi Sosial 2 Kenakalan Remaja. Jakarta: PT Raja Grafindo Persada

Nasir, Sahilul A. (2002). Peranan Pendidikan Agama Terhadap Pemecahan Problem Remaja. Jakarta: Kalam Mulia

Syafaat, Aat. (2008). Peranan Pendidikan Islam dalam Mencegah Kenakalan Remaja. Jakarta: Raja Grafindo Persada

Sudarsono. (2005). Etika Islam Tentang Kenakalan Remaja. Jakarta: PT Rineka Cipta

Sudarsono. (2012). KenakalanRemaja. Jakarta: PT Rineka Cipta.

Saidah, Karimatus. (2008). Implementasi Pendidikan Karakter melalui Pengenalan Nilai-Nilai Kearifan Lokal di SDN Burengan 2 Kota Kediri. Jurnal Tarbiyatuna, Volume2 Nomor $1 . \quad$ (Online), (htttp://ejournal.iaiibrahimy.ac.id/tarbiyatuna), diakses 20 Desember 2018

Wahab, Rohmalina. (2015). Psikologi Agama. Jakarta: PT Raja Grafindo Persada

Zuhdiyah. (2012). Psikologi Agama. Yogyakarta: Pustaka Felicha 